\begin{tabular}{|l|l|l||}
\hline \multicolumn{2}{|c|}{ PublisherInfo } \\
\hline \hline PublisherName & $:$ & BioMed Central \\
\hline \hline PublisherLocation & $:$ & London \\
\hline \hline PublisherImprintName & $:$ & BioMed Central \\
\hline \hline
\end{tabular}

\title{
RCUK draft mandates open access
}

\begin{tabular}{|l|l|l||}
\hline \multicolumn{2}{|c|}{ ArticleInfo } \\
\hline \hline ArticleID & $:$ & 5098 \\
\hline \hline ArticleDOI & $:$ & $10.1186 /$ gb-spotlight-20050624-01 \\
\hline \hline ArticleCitationID & $:$ & spotlight-20050624-01 \\
\hline \hline ArticleSequenceNumber & $:$ & 74 \\
\hline \hline ArticleCategory & $:$ & Research news \\
\hline ArticleFirstPage & $:$ & 1 \\
\hline \hline ArticleLastPage & $:$ & 3 \\
\hline \hline & & RegistrationDate : 2005-6-24 \\
\hline ArticleHistory & $:$ & OnlineDate \\
\hline \hline ArticleCopyright & $:$ & BioMed Central Ltd2005-6-24 \\
\hline \hline ArticleGrants & $:$ & \\
\hline \hline ArticleContext & $:$ & 130596611 \\
\hline \hline
\end{tabular}




\section{Stephen Pincock}

Email: Stephen.pincock@thescientisteurope.com

Papers arising from work funded by the Research Councils UK (RCUK) should be deposited in an open access repository "at the earliest opportunity, wherever possible at or around the time of publication, in accordance with copyright and licensing arrangements," according to a draft policy that RCUK will make public next week.

The wording of the document has been carefully chosen in order "not to over-rule any existing copyright agreements," said Astrid Wissenburg from the Economic and Social Research Council, who is coordinating the development of the policy. Earlier drafts had specified a time frame within which articles had to be deposited, similar to the policy recently implemented by the Wellcome Trust.

"But we came to the conclusion that any specific figure would be largely plucked out of the air," Wissenburg told The Scientist. This is particularly the case for RCUK, which funds a much wider range of academic disciplines than the Wellcome Trust or the US National Institutes of Health (NIH), she said, each of which has its own hugely different publishing culture.

RCUK, the umbrella group for the United Kingdom's eight government-funded research councils, will publish the current draft on its Web site early next week, giving interested parties until the end of August to register their comments.

RCUK has already been through an extensive consultation including the university sector and others about the policy statement, and had been considering conducting a similar closed consultation with the publishers of learned journals. But a decision was taken this week to make a public consultation the last phase in the development of the policy statement. Learned societies in particular will be invited by letter to comment.

Peter Suber, an open access advocate from Earlham College, Richmond, Indiana, told The Scientist he found the phrase "in accordance with copyright and licensing arrangements" incoherent and unhelpful.

"I don't think it will tell authors or publishers (or eventually, courts) who may do what or who may block whom from doing what," Suber said via E-mail. "Publishers hold copyright on the copy-edited version of the peer-reviewed manuscript. If the purpose of the clause is simply to tell authors that they may not deposit the copy-edited version without publisher consent, and that they may deposit earlier versions without publisher consent, then it could say so much more directly and clearly. Because this distinction is easy to express and common in other funding-agency policies (such as the NIH policy), I suspect that the RCUK policy is trying to get at something else. But it's far from clear what else the clause might mean."

Wissenburg said RCUK was aware that some open access advocates were concerned that by not specifying a time within which articles must be published, the policy could leave scope for publishers to enact restrictive copyright agreements to delay the point at which articles become freely available.

"At the moment, we're opening it up so everyone can play fair," she said. "We see this very much as a starting point from which we can move forward together with all stakeholders." But the policy is due for 
a formal review in 2008, and it isn't out of the question that RCUK would consider revising it earlier if any group was seen to be taking advantage, she said.

The policy as it stands would apply only to new grants awarded after October 1, 2005, meaning that the real impact of the policy would not be felt for a couple of years. "There is actually quite a lot of time left to discuss all of this," Wissenburg said.

\section{References}

1. S. Pincock, "Wellcome insists on open access," The Scientist, May 19, 2005. , [http://www.thescientist.com/news/20050519/01]

2. T. Agres, "NIH announces 'open-access' rules," The Scientist, Feb. 4, 2005., [http://www.thescientist.com/news/20050204/02]

3. S. Pincock, "UK gov't unsure on open access," The Scientist, Feb. 3, 2005., [http://www.thescientist.com/news/20050203/01]

4. Peter Suber, [http://www.earlham.edu/ peters/hometoc.htm] 